\title{
軸方向圧縮力と単調逆対称曲げモーメントを受ける角形鋼管柱の実験的研究 EXPERIMENTAL STUDY ON SQUARE STEEL TUBULAR COLUMNS UNDER COMPRESSIVE AXIAL FORCE WITH MONOTONIC ANTISYMMETRIC BENDING MOMENT
}

\author{
佐 藤 篤司*, 三井和 也** \\ Atsushi SATO and Kazuya MITSUI
}

\begin{abstract}
Recommendation for Limit State Design of Steel Structure (LSD) specifies the requirements for columns to guarantee sufficient strength and ductility. However, specific deformation capacity of the column which is subjected to compressive axial force with antisymmetric bending moment is not shown. Moreover, second-order effect under these condition is not investigated by testing. In this study, testing where axial force with antisymmetric bending moment are applied to the columns simultaneously are conducted. Moment capacity, deformation capacity and the second-order effects that will be caused by $P \delta$ moment were evaluated from test results. Comparison between LSD requirements and test results were also shown.
\end{abstract}

Keywords : Square steel tubural column, Axial force ratio, Slenderness ratio, Maximum bending moment, Plastic deformation capacity, $P \delta$ moment 角形鋼管柱, 軸力比, 細長比, 最大曲げモーメント, 塑性変形能力, $P \delta$ モーメント

1. はじめに

箱形断面部材や角形鋼管部材といつた矩形中空断面部材は，閉断 面であり直行する 2 方向に対し耐力・剛性が等しいといった断面特 性上の利点を有していることから, 建築構造物の柱材として広く使 用されている. ラーメン架構に水平力が作用すると, 柱には軸方向 力とともに水平力に抵抗するせん断力が生じ, 複曲率曲げモーメン トが作用する，柱の応力状態（軸方向力と曲げモーメントの組合せ 応力）の変化は柱の耐力や弾塑性挙動に影響を及ぼすことから, 我 が国ではこれらの影響を考慮した軸方向力と曲げモーメントの設計 耐力式が各指針・規準に示されている ${ }^{1) \sim 4)}$. 鋼構造限界状態設計指 針・同解説 ${ }^{1)}$ (以後, LSD 指針と称す) では軸方向力と曲げモーメン トによる耐力相関式のみならず，柱材板要素の幅厚比に応じた区分， 曲げ材の細長比区分および軸力比と細長比の制限による柱区分を示 している. 軸力比と細長比の制限による柱区分において, 塑性ヒン ジを形成する柱に対しては，以下の制限を満たすこととしている. $n_{y} \leq 0.75$

$n_{y} \cdot \lambda_{c 0}^{2} \leq 0.10(1+\kappa)$

$(-0.5 \leq \kappa \leq 1.0)$

$n_{y}$ は柱の降伏軸力 $N_{y}$ に対する作用軸方向圧縮力 $N$ の比率 $\left(=N / N_{y}\right)$, $\lambda_{c 0}$ は柱の曲げ面内細長比である。なお，本論文において材長 $L$ を座 屈長さとする柱は曲げ面内細長比を $\lambda_{\mathrm{c} 0}$ により, 座屈長さ $\mathrm{k}_{\mathrm{c}} \mathrm{L}$ による 曲げ面内細長比を $\lambda_{c}$ により表現する．曲げ面内細長比 $\lambda_{c 0}$ の算定式を (3) 式に，曲げ面内細長比 $\lambda_{c 0}$ の算定式を (4) 式に示す.

$$
\begin{aligned}
& \lambda_{c 0}=1 / \pi \cdot \sqrt{\sigma_{y} / E} \cdot L / i_{x} \\
& \lambda_{c}=1 / \pi \cdot \sqrt{\sigma_{y} / E} \cdot k_{c} \cdot L / i_{x}
\end{aligned}
$$

$\kappa$ は柱の材端曲げモーメント比 $\left(=\mathrm{M}_{2} / \mathrm{M}_{1},\left|M_{1}\right| \geq\left|M_{2}\right|\right)$ であり, 逆 対称曲げでは $\kappa=1.0$, 複曲率曲げのときを正とする。 $\sigma_{y}$ は降伏応力 度, E はヤング係数, L は材長, $\mathrm{I}_{\mathrm{x}}$ は曲げ面内での断面二次半径であ る. 制限式 (1) は軸方向圧縮力が極女て大きくなると, 柱のたわみに 伴う付加曲げモーメントなどにより不安定挙動を起こしやすくなる ため, その現象を防ぐ制限である. 制限式 (2) は, 柱端部に塑性ヒン ジを形成する柱に対し, 軸方向力を保持した状態で塑性変形能力を 確保するための軸力比と細長比による制限である。軸方向圧縮力と 一端単調曲げモーメントを受ける柱に対しては, 制限式 (2)を満たす ことで担保できる塑性変形能力 $R\left(=\theta / \theta_{\mathrm{PN}}-1\right)$ が $3 \sim 5$ 以上であるとし ているが，軸方向圧縮力と逆対称曲げモーメントを受ける柱に対し ては，制限式を満たすことで担保できる塑性変形能力の具体的な数 值を示していない $\left(\theta_{\mathrm{PN}}\right.$ は軸方向力を考慮した全塑性モーメントに対 応する弾性回転角).

骨組に水平力が作用すると節点は水平移動し，柱に曲げモーメン トが作用するとたわみが生じる，層間の水平変位 $\Delta$ は $P \Delta$ 効果による 付加曲げモーメント (PA モーメント) を，柱のたわみ $\delta$ は $P \delta$ 効果 による付加曲げモーメント（ $P \delta$ モーメント）を発生させる，既往研 究において $P \Delta$ モーメントに関する検討 $\left.{ }^{5)}{ }^{12}\right)$ や $P \delta$ モーメントに関
* 名古屋工業大学大学院工学研究科 准教授·博士 (工学

** 名古屋工業大学大学院創成シミュレーション工学専攻 博士後期課程 · 修士 (工学)
Assoc. Prof., Graduate School of Engineering, Nagova Institute of Technology, Dr.Eng. Doctoral Student, Dept. of Scientific and Engineering Simulation, Nagoya Institute of Technology 


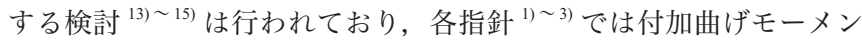
トの影響が考慮された設計式が与えられている。これまでに，節点 移動のある柱の実験的研究は比較的多(実施されているが ${ }^{5) \sim 12), ~ た ~}$ わみによって生じる $P \delta$ モーメント分布と変形性状に着目した実験的 研究はほとんど実施されておらず，軸方向圧縮力と一端単調曲げモー メントを受ける $\mathrm{H}$ 形断面柱を対象とした実験が行われているのみで あるため ${ }^{16)}{ }^{18)}, P \delta$ モーメントが角形鋼管柱の実挙動に与える影響 は不明な部分が多い, 柱の応力状態・材長によっては, $P \delta$ 効果によ る付加曲げモーメントが柱の耐力・変形能力を低下させる要因とな り, 骨組の不安定挙動の要因となるため, $P \delta$ 効果の影響を解明する ことは必要である。

筆者はこれまでに軸方向圧縮力と一端単調曲げモーメントを受け る角形鋼管柱の実験結果を報告し，最大曲げモーメント，塑性変形 能力および変形性状を明らかにした ${ }^{19)}$. しかし，ラーメン架構に水 平力が作用すると, 柱には複曲率曲げモーメントが作用することが 大半であり，柱の材端曲げモーメント比の影響を実験的に解明する必 要がある，そこで，本論文では軸方向圧縮力と単調逆対称曲げモー メントを受ける角形鋼管柱の最大曲げモーメント, 塑性変形能力お よび変形性状を明らかにすべく, 軸力比, 細長比をパラメータとし た実験を行い，LSD 指針に示されている終局限界状態設計における 柱材の設計式と実験結果の比較・検討を行う。これらに加え, $P \delta$ 効 果による付加曲げモーメント（PS モーメント）の詳細な検討を行う.

\section{2. 軸方向圧縮力と単調逆対称曲げモーメントを受ける角形鋼管柱の 実験}

\section{1. 試験体計画}

軸方向圧縮力と単調逆対称曲げモーメントを受ける角形鋼管柱の 最大曲げモーメント，塑性変形能力および変形性状を把握するた めの実験を実施する，本実験で使用する柱材は冷間成形角形鋼管の STKR400であり, 断面形状は $\square-125 \times 125 \times 6$ である. 公称幅厚比は 20.8 であり，LSD 指針の P-I-1 区分を満足した值である。試験体パラ メータには軸力比および細長比を設定した．Fig.1 に試験体の全体図 を示す。柱の両端には試験装置に設置するため, 厚さ $32 \mathrm{~mm}$ のエン ドプレートが溶接されている.

Table 1 に JIS 5 号試験片による鋼材の機械的性質を，Table 2 に短 柱圧縮試験結果を, Table 3 に実験で使用した角形鋼管の断面諸性能 を示す。素材試験片は角形鋼管のシーム溶接部を除く 3 面の平板部 から各 1 本ずつ採取し，その平均值を Table 1 に示している. Fig. 2 の 素材引張試験から得た応力度 - 歪度関係に示すように, $0.2 \%$ オフセッ 卜耐力を降伏応力度 $\sigma_{y}$ とした。 なお, 歪の計測は歪ゲージにより行っ
た. Table 2 に示す短柱圧縮試験は断面せいの 3 倍 $(375 \mathrm{~mm})$ を試験 体の材長とした。短柱圧縮試験の試験体の部材両端は，加圧板を接 合せず，平坦に機械加工した。Fig.3 に示す短柱圧縮試験概要図のよ うに，載荷時には試験体に貼付した歪ゲージの值を読み取り，荷重 心と試験体の図心を一致させ，単調軸圧縮載荷を実施した。試験体 の変位については, 軸方向の変位量を角形鋼管の平板部の中央部の 近くに対称に配置した 4 つ変位計によって測定し, これらの平均 值を試験体の変形とした。短柱圧縮試験の試験体は 2 体であり, 試 験結果の平均值を Table 2 に, 荷重 - 変位関係を Fig.4 に示している. 本論文において短柱圧縮試験の降伏軸力 ${ }_{5} \mathrm{~N}_{\mathrm{y}}$ は初期軸剛性に対し軸剛 性が 3 分の 1 に低下した時点の荷重と定義した ${ }^{20)}$. Fig.4 中の破線は 短柱圧縮試験の降伏軸力 $\mathrm{N}_{\mathrm{N}} \mathrm{N}$ の平均值と Table 3 に示す実測值により 求めた断面積 $\mathrm{A}$ と素材引張試験により得た降伏応力度 $\sigma_{\mathrm{y}}$ を乗じるこ とで求めた降伏軸力 $N_{\mathrm{y}}$ である. Table 3 に示す断面諸性能は短柱の実 測寸法と Table 1 の降伏応力度 $\sigma_{y}$ に基づいて算定を行った。試験体の 材長 L は $2800 \mathrm{~mm} ， 3200 \mathrm{~mm} ， 3600 \mathrm{~mm} ， 4200 \mathrm{~mm}$ の 4 種類である. 本 論文で対象とした曲げモーメント分布は逆対称曲げであるため, 柱 の材端曲げモーメント比 $\kappa$ は $\kappa=1.0$ となる. Table 4 に示す $\lambda_{c 0}$ は素

Table 1 Material properties from coupon test

\begin{tabular}{c|c|c|c|c|c}
\hline $\mathrm{t}_{\mathrm{b}}$ & $\mathrm{E}$ & $\sigma_{\mathrm{y}}$ & $\sigma_{\mathrm{u}}$ & $\mathrm{E}_{\text {long }}$ & Y.R. \\
\hline 6.0 & 211700 & 411.6 & 443.1 & 34.5 & 92.9 \\
\hline
\end{tabular}

$\mathrm{t}_{\mathrm{b}}$ : Nominal thickness [mm], E: Young's modulus [N/mm $\left.{ }^{2}\right], \sigma_{\mathrm{y}}$ : Yield stress [N/ $\left.\mathrm{mm}^{2}\right], \sigma_{\mathrm{u}}$ : Ultimate stress $\left[\mathrm{N} / \mathrm{mm}^{2}\right], \mathrm{E}_{\text {long }}$ : Elongation [\%], Y.R.: Yield ratio[\%]

Table 2 Test results from stub column test

\begin{tabular}{c|c|c|c|c}
\hline$t_{b}$ & ${ }_{5} \mathrm{~N}_{\mathrm{y}}$ & ${ }_{5} \mathrm{~N}_{\max }$ & $\mathrm{N}_{\mathrm{y}}$ & ${ }_{s} \mathrm{~N}_{\mathrm{y}} / \mathrm{N}_{\mathrm{y}}$ \\
\hline 6.0 & 1071 & 1255 & 1101 & 0.972 \\
\hline
\end{tabular}

${ }_{5} \mathrm{~N}_{\mathrm{y}}$ : Yield strength from stub column tests $[\mathrm{kN}],{ }_{s} \mathrm{~N}_{\text {max }}$ : Maximum strength from stub column tests $[\mathrm{kN}], \mathrm{N}_{\mathrm{y}}$ : Calculated yield strength $[\mathrm{kN}]$

Table 3 Geometrical dimensions of cross section

\begin{tabular}{c|c|c|c|c|c|c|c|c}
\hline Cross section & $\mathrm{B}$ & $\mathrm{t}$ & $\mathrm{B} / \mathrm{t}$ & $\mathrm{R}_{\text {out }} \mathrm{t}$ & $\mathrm{A}$ & $\mathrm{I}$ & $\mathrm{Z}_{\mathrm{p}}$ & $\mathrm{M}_{\mathrm{p}}$ \\
\hline$\square-125 \times 125 \times 6$ & 125.0 & 5.763 & 21.7 & 1.79 & 2674 & 624.8 & 118.4 & 48.75 \\
\hline
\end{tabular}

B: Width [mm], t:Thickness $[\mathrm{mm}], \mathrm{R}_{\text {out }}$ Outer radius $[\mathrm{mm}], \mathrm{A}$ : Area $\left[\mathrm{mm}^{2}\right]$,

$\mathrm{I}$ : Moment of inertia $\left[\times 10^{4} \mathrm{~mm}^{4}\right], \mathrm{Z}_{\mathrm{p}}$ : Plastic section modulus $\left[\times 10^{3} \mathrm{~mm}^{3}\right]$,

$\mathrm{M}_{\mathrm{p}}:$ Full plastic bending moment $[\mathrm{kN} \cdot \mathrm{m}]$

Table 4 Geometrical dimensions in longitudinal direction

\begin{tabular}{c|c|c|c}
\hline Cross section & $\mathrm{L}$ & $\lambda$ & $\lambda_{\mathrm{c} 0}$ \\
\hline \multirow{4}{*}{$\square-125 \times 125 \times 6$} & 2800 & 57.9 & 0.813 \\
\cline { 2 - 4 } & 3200 & 66.2 & 0.929 \\
\cline { 2 - 4 } & 3600 & 74.5 & 1.045 \\
\cline { 2 - 4 } & 4200 & 86.9 & 1.219 \\
\hline
\end{tabular}

$\mathrm{L}$ : Length $[\mathrm{mm}], \lambda:$ Slenderness ratio $\left(=\mathrm{L} / \mathrm{i}_{\mathrm{x}}\right), \lambda_{\mathrm{co}}$ : Flexural slenderess ratio based on measured yield stress

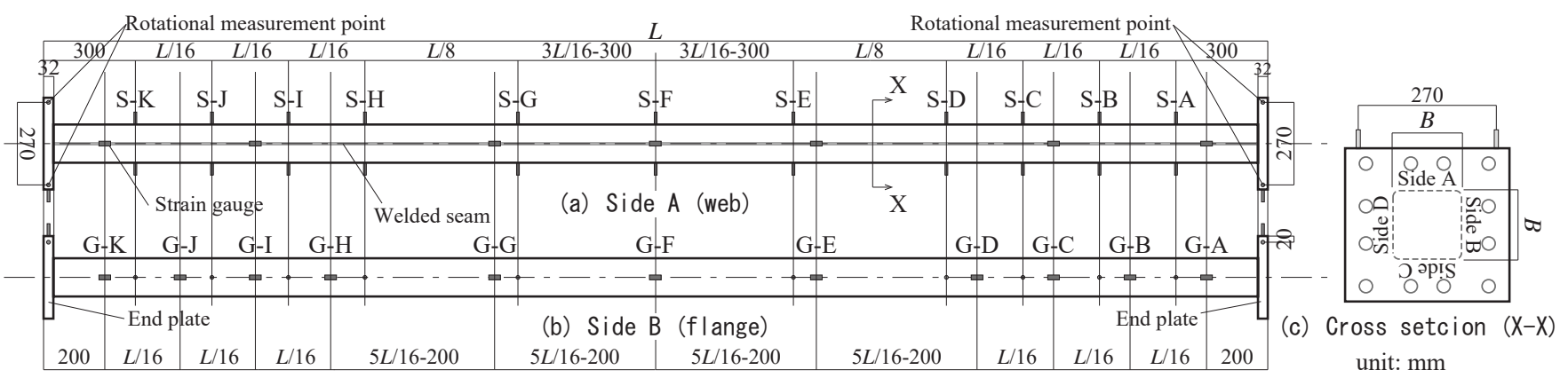

Fig. 1 Test specimen (Plan view) 
材引張試験より得た降伏応力度 $\sigma_{\mathrm{y}}$ に基づいて算定した柱の曲げ面内 細長比であり，材長 $L$ に基づいて算定している，なお，本論文では 素材引張試験より得た降伏応力度 $\sigma_{\mathrm{y}}$ に基づき算定した軸力比 - 曲げ 面内細長比 $\lambda_{c 0}$ 関係を用いて実験結果の考察を行う。全試験体と LSD 指針の軸力比と細長比による制限式との対応関係を Fig.5 に示す. Fig. 5 中の番号は Table 5 に示す試験体番号である. Fig.5 には, 軸方 向圧縮力と単調逆対称曲げモーメントを受ける柱の柱材端に生じる 塑性ヒンジの塑性変形能力を確保するための制限式 (2) と柱材端に初 期降伏が生じる条件式 $(5)^{1,21)}$ を同時に示している.

$$
n_{y} \cdot \lambda_{c 0}^{2} \leq 0.25(1+\kappa)
$$

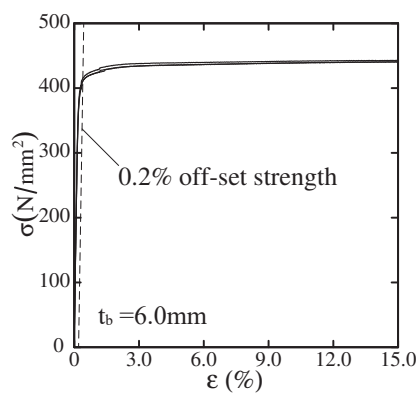

Fig. 2 Stress - strain relationships

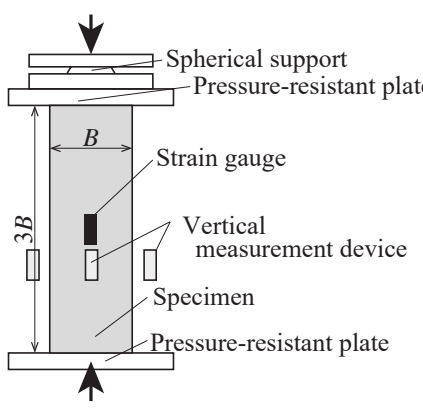

(a) Test set-up

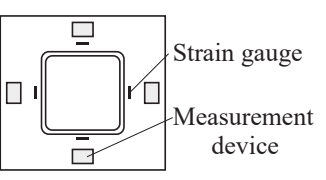

(b) Cross section

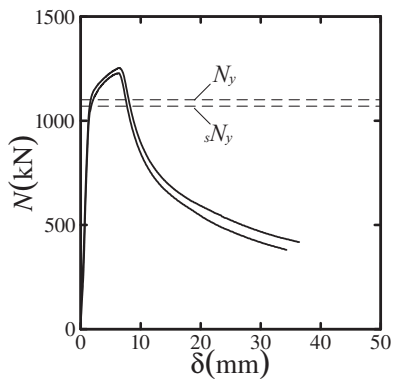

Fig. 4 Results of stub column tests

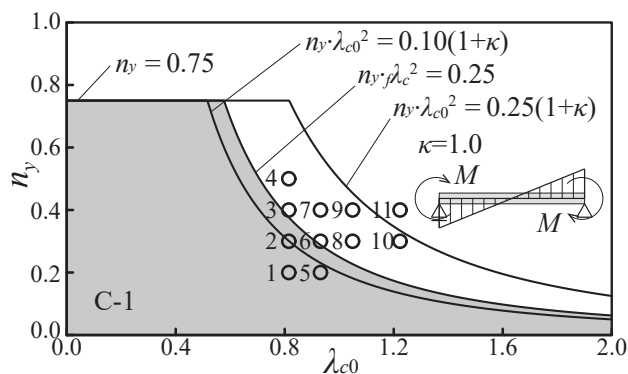

Fig. 5 Comparison between specimens and LSD I imitaions
LSD 指針に示される制限式 (2) は条件式 (5)の数值 0.25 を 0.10 と 小さく設定することで定められたものである ${ }^{1)}{ }^{18)}$. 素材引張試験より 得た降伏応力度 $\sigma_{y}$ に基づく曲げ面内細長比 $\lambda_{c 0}$ により試験体を評価す ると, No.11 を除く試験体は, 柱材端に初期降伏が生じる領域内に存 在する。また, No.1, No.2 および No. 5 の試験体は塑性変形能力を確 保できるとする制限式 (2)の領域内に存在する.

LSD 指針では，終局状態において塑性ヒンジが形成される骨組， 特に高軸方向圧縮力が作用する骨組および高層骨組における「フレー ムスタビリティ」を確保するために, (1) 式に加え (6) 式を設けており, これらの制限を満たす柱を C-1 区分としている ${ }^{1)}$. Fig.5 に示すよう に，C-1 区分となる軸力比と細長比の組合せは灰色で塗られた領域で ある。ここで，(6) 式中の $\mathrm{f} \lambda_{\mathrm{c}}$ は構面内の柱の曲げ座屈細長比であり， 曲げ座屈細長比 $\lambda_{c}$ に等しい.

$$
n_{y} \cdot f \lambda_{c}^{2} \leq 0.25
$$

本実験は逆対称曲げ $(\kappa=1.0)$ を受ける柱を対象としており，試験 体の材長 $L$ が座屈長さとなることから (2.2 節参照)，No.1，No.2 お よびNo.5 の試験体は LSD 指針が示す C-1 区分に属する. Table 5 に試 験体一覧を示す. Table 5 中の $M_{\mathrm{pc}}$ は軸方向力を考慮した全塑性モーメ ントであり ${ }^{1), 21)}, \theta_{\mathrm{pc}}$ は座屈たわみ角法に基づいて算定される軸方向力 を考慮した全塑性モーメント $M_{p c}$ に対応する弾性回転角である ${ }^{21)}$ ．以 下に軸方向力を考慮した全塑性モーメント $M_{p c}$ の算定式を示す.

$$
\begin{aligned}
& n_{y} \leq \frac{r_{w}}{2+r_{w}} \text { のとき } \quad M_{p c}=\left\{1-\frac{\left(2+r_{w}\right)^{2}}{r_{w}\left(4+r_{w}\right)} n_{y}^{2}\right\} M_{p} \\
& n_{y}>\frac{r_{w}}{2+r_{w}} \text { のとき } \quad M_{p c}=\frac{2\left(2+r_{w}\right)}{4+r_{w}}\left(1-n_{y}\right) M_{p} \\
& \text { ただし } r_{w}=\frac{2(B-2 t)}{B}
\end{aligned}
$$

本研究において, 導入軸方向圧縮力 $\mathrm{N}_{\mathrm{t}}$ は, Table 1 に示す素材引張 試験より得た降伏応力度 $\sigma_{\mathrm{y}}$ に Table 3 に示す短柱の実測寸法に基づく 断面積 $\mathrm{A}$ を乗じることで求めた降伏軸力 $\mathrm{N}_{\mathrm{y}}\left(=\mathrm{A} \cdot \sigma_{\mathrm{y}}\right)$ に基づいて算出し た。 その值を Table 5 に示している。 なお，降伏軸力 $\mathrm{N}_{\mathrm{y}}$ は Table 2 に 示す短柱圧縮試験結果の降伏軸力 $\mathrm{N}_{\mathrm{y}}$ とほぼ同值であった。試験体名 は記号「B」に続く数字が断面せいを,「bt」に続く数字が公称幅厚比を, $\ulcorner$ ny」に続く数字が軸力比を, 「L」に続く数字が材長を意味している.

\section{2. 実験計画 (計測計画 · 載荷計画)}

\begin{tabular}{|c|c|c|c|c|c|c|c|}
\hline Name & No. & $\mathrm{L}$ & $\mathrm{n}_{\mathrm{y}}$ & $\mathrm{n}_{\mathrm{y}} \cdot \lambda_{\mathrm{c} 0}{ }^{2}$ & $\mathrm{~N}_{\mathrm{t}}$ & $M_{p c}$ & $\theta_{p c}$ \\
\hline B125bt21ny020L2800 & 1 & \multirow{4}{*}{2800} & 0.20 & 0.132 & 220.2 & 46.06 & 0.0166 \\
\hline B125bt21ny030L2800 & 2 & & 0.30 & 0.198 & 330.2 & 42.70 & 0.0156 \\
\hline B125bt21ny040L2800 & 3 & & 0.40 & 0.264 & 440.3 & 37.99 & 0.0140 \\
\hline B125bt21ny050L2800 & 4 & & 0.50 & 0.330 & 550.4 & 31.98 & 0.0120 \\
\hline B125bt21ny020L3200 & 5 & \multirow{3}{*}{3200} & 0.20 & 0.173 & 220.2 & 46.06 & 0.0191 \\
\hline B125bt21ny030L3200 & 6 & & 0.30 & 0.259 & 330.2 & 42.70 & 0.0180 \\
\hline B125bt21ny040L3200 & 7 & & 0.40 & 0.345 & 440.3 & 37.99 & 0.0163 \\
\hline B125bt21ny030L3600 & 8 & \multirow{2}{*}{3600} & 0.30 & 0.328 & 330.2 & 42.70 & 0.0205 \\
\hline B125bt21ny040L3600 & 9 & & 0.40 & 0.437 & 440.3 & 37.99 & 0.0186 \\
\hline B125bt21ny030L4200 & 10 & \multirow{2}{*}{4200} & 0.30 & 0.446 & 330.2 & 42.70 & 0.0245 \\
\hline B125bt21ny040L4200 & 11 & & 0.40 & 0.594 & 440.3 & 37.99 & 0.0224 \\
\hline
\end{tabular}

Fig.6 に境界条件と実験装置概要を示す. Fig.1 および Fig.6に示す ように，水平変位計を 11 断面に計 22 ケ所（S-A 断面, S-B 断面, S-C 断面，‥, S-K 断面)，鉛直変位計も同断面位置に計 11 ケ所（S-A 断

Table 5 List of specimens 
面, S-B 断面, S-C 断面，‥, S-K 断面）設置し，曲げ面内・面外の変 位方向の変位履歴が計測できるようにした。柱の両端部には材端の 回転角を計測するため, 柱端部に 2 ケ所ずつ変位計を設置した。ま た, 載荷中の材長方向歪分布が計測できるように Fig.1 に示す位置に 歪ゲージを貼付した (G-A 点, G-B 点, G-C 点, $\cdots$, G-K 点)。冷間成 形角形鋼管の STKR 400 には製造工程上，シーム溶接が平板部の 1 平 面に生じる. シーム溶接部の鋼材特性は平板部の鋼材特性と異なる ことが報告されている ${ }^{22,23)}$. したがって，本論文ではシーム溶接部 が角形鋼管柱の最大曲げモーメント・塑性変形能力に与える影響を 小さくするため, 試験体は側面 A（シーム溶接面）が上面となるよ うに設置し，側面 $\mathrm{A}$ および側面 C をウェブ，側面 B および側面 D を フランジと定義する．載荷は Table 5 に示す目標とする導入軸方向圧 縮力 $\mathrm{N}_{\mathrm{t}}$ を試験体に導入した後, Fig.6(a) に示す柱の両材端に $\mathrm{x}$ 軸まわ りの逆対称曲げモーメントを加えた。軸方向圧縮力はリニアシステ ムにより柱材軸方向に水平移動が可能な装置側から $1000 \mathrm{kN}$ ジャッキ を用いて, 目標とする軸方向圧縮力 $\mathrm{N}_{\mathrm{t}}$ が常に一定に保たれるように 自動制御により載荷を行った。荷重は軸方向力載荷点に設置したロー ドセルにより計測した。なお, 軸方向力載荷時には図心位置と載荷 軸が一致し, 偏心が生じないように歪ゲージの值を読み取り, 試験 体位置を調整した。逆対称曲げモーメントはセンターホールジャッ キを用いて, Fig.6(b) に示すように載荷梁に緊結した PC 鋼棒で偶力 $\mathrm{P}$ として導入し，ロードセルにより計測した PC 鋼棒の張力と偶力間 距離 $(1000 \mathrm{~mm})$ により曲げモーメントを算出した。逆対称曲げモーメ ントを実現するため, 両端のセンターホールジャッキには常に等し い荷重P が作用する機構とした。両端の支持条件はピン支承とロー ラー支承であり, 回転軸はx 軸まわりの回転のみを許容している. 両端に設置したピン治具は摩擦による抵抗を限りなく小さくするた

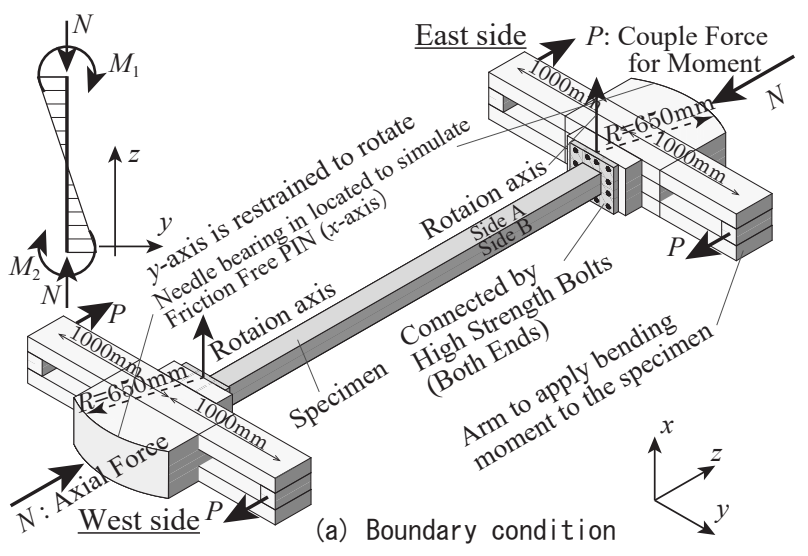

Horizontal measurment devices

z-direction Rotational measurment devices Linear Motion Guide (THK)

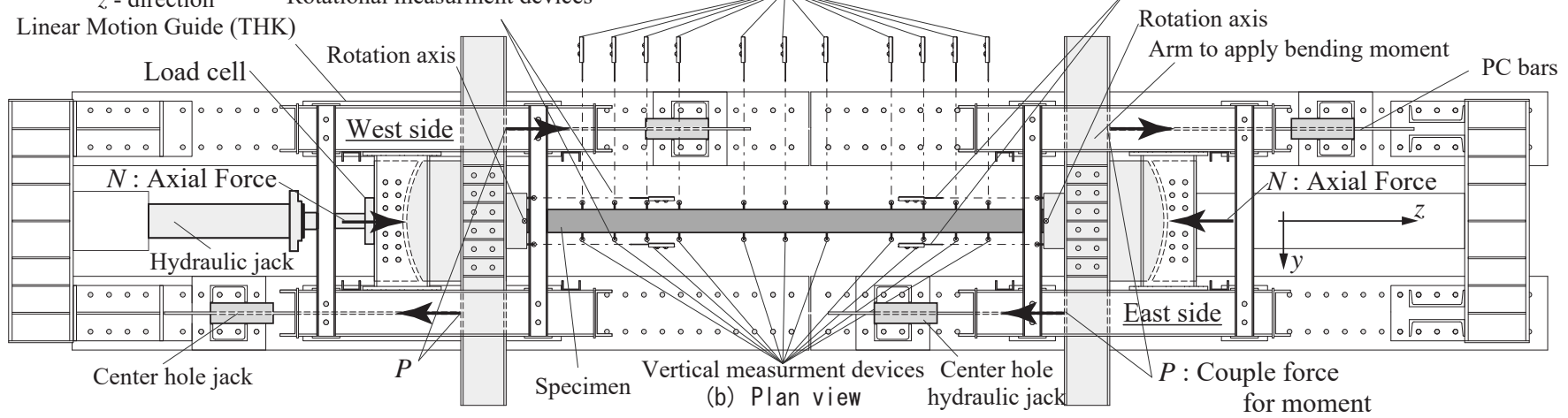

Fig. 6 Boundary condition and test set-up
め，四面と凸面の間に複数のニードルベアリングを配置し，軸方向 力作用時も回転に追従できるように支持されている，その回転中心 は, Fig.6(a)に示すように, 試験体エンドプレートとピン治具が接触 する位置となるように設計されている。なお，この実験装置を検証 する実験を佐藤・小野ら ${ }^{24)}$ が実施しており, 実験装置の実用性が確 認されている。本実験も同じ実験装置を使用していることから，境 界条件は正しく再現できていると言える。載荷は試験体が軸方向圧 縮力を保持できなくなるまで, または, ピン治具の最大ストローク （0.30 rad 程度）に到達するまで実験を行った。

\section{3. 実験結果}

\section{1. 載荷点での曲げモーメント - 回転角関係}

Table 6 に実験結果一覧を, Fig.7 に両端の載荷点での曲げモーメ ント - 回転角関係を示す。縦軸の M はロードセルにより算出された 作用曲げモーメントを, 横軸の $\theta$ は材端回転角である。実線は Fig.6 に示す East 側での曲げモーメント - 回転角関係，破線は Fig.6 に示 す West 側での曲げモーメント - 回転角関係である. Fig.8 は Fig.7 の 縦軸を $M_{\mathrm{pc}}$ により無次元化し, 横軸を $\theta_{\mathrm{pc}}$ により無次元化した結果で ある。材端回転角は最大曲げモーメント以降で, East側または West 側の一方向で進行していくため, Fig.8 には材端回転角が進行した側 の曲げモーメント - 回転角関係を示している. Fig. 8 中に示す一点 鎖線は計算により求めた初期弾性剛性を示す直線であり, Fig.7 およ び Fig.8 に示す各曲線の番号は Table 6 に記載した試験体番号である. Fig.9 には West 側から撮影した載荷終了後の試験体の変形性状を示 す. Table 6 に示した C.M. は本実験で確認された 3 種類の試験体の崩 壊形式であり，Lは片側の曲げモーメント載荷点付近に発生した局部 座屈により載荷点の最大曲げモーメントおよび変形能力が決定され た試験体（以後，C.M.: L と称す）を，P は 3.5 節で後述する $P \delta$ モー メントにより載荷点での最大曲げモーメントおよび変形能力が決定さ れ，その後，局部座屈が生じることがなく部材の曲げ面内の変形が一 方向に進行し, 載荷点から $0.3 \mathrm{~L}$ 程度離孔た位置の曲げ面内変位が最 大となった試験体 (以後, C.M.:P $P \delta$ 称す) を, $P \delta+\mathrm{L}$ は $P \delta$ モーメ ントによる変形で載荷点での最大曲げモーメントが決定され，その 後, $P \delta$ モーメントの影響により生じる曲げ面内の最大変位位置に顕 著な局部座屈変形が生じ, 変形能力が決定された試験体（以後, C.M.: $P \delta+\mathrm{L}$ と称す）を意味する。なお, 崩壊形式の分類は載荷中に観察さ れた試験体の挙動, 3.3 節で述べる試験体に貼付した歪ゲージから得 た材長方向の歪分布, 3.4 節で述べる曲げ面内の変位履歷, 3.5 節で 


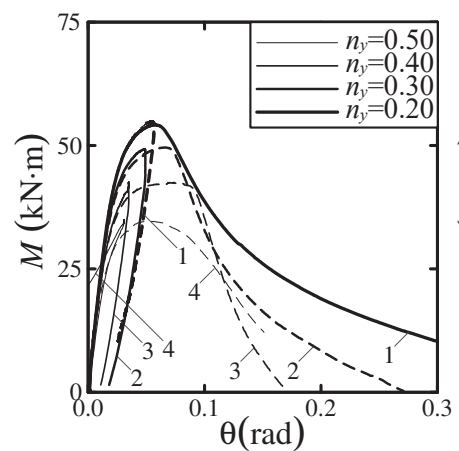

(a) L2800 series

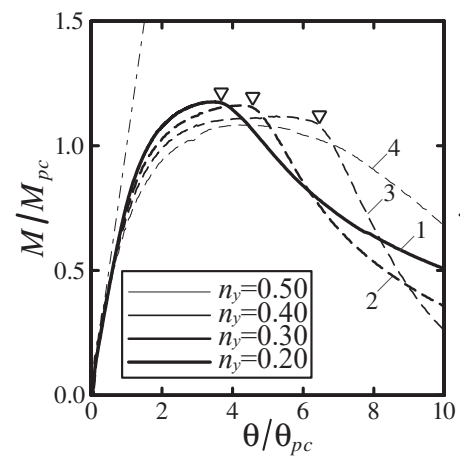

(a) L2800 series

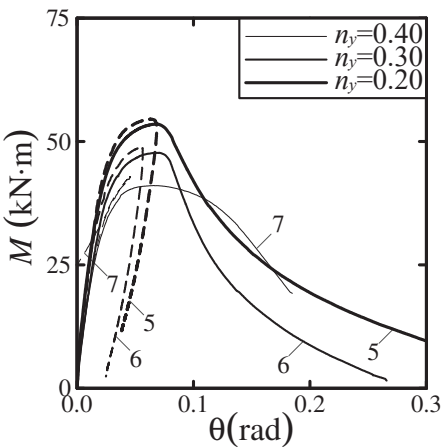

(b) L3200 series

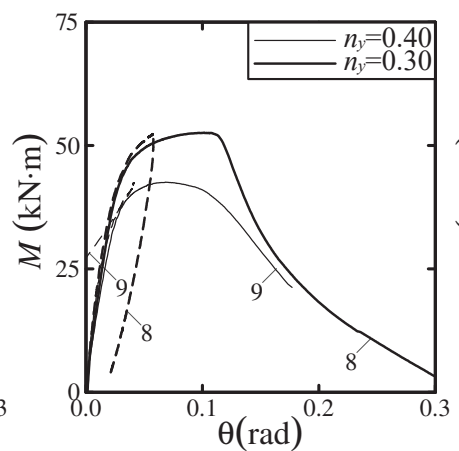

(c) L3600 series

Fig. 7 Relationship between $\boldsymbol{M}$ and $\boldsymbol{\theta}$

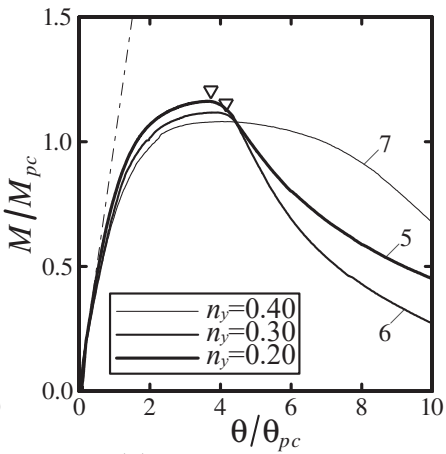

(b) L3200 series

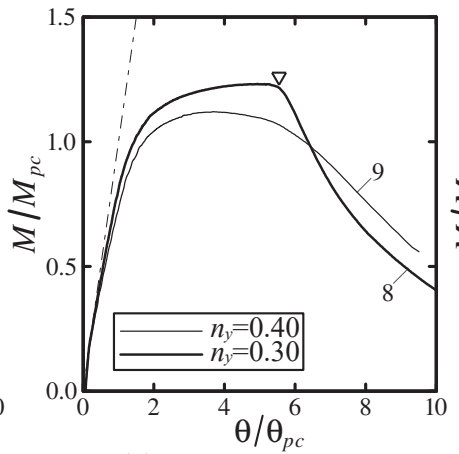

(c) $\mathrm{L} 3600$ series
$\boldsymbol{M} / \boldsymbol{M}_{\boldsymbol{p c}}$ and $\boldsymbol{\theta} / \boldsymbol{\theta}_{\boldsymbol{p c}}$

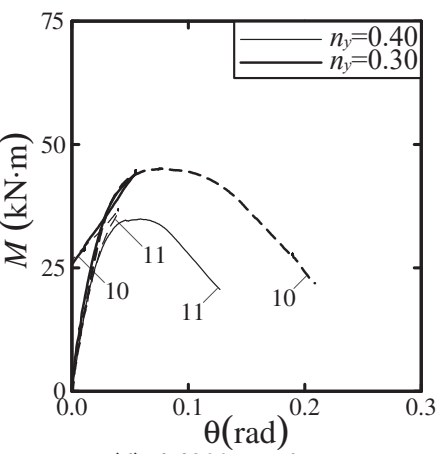

(d) L4200 series

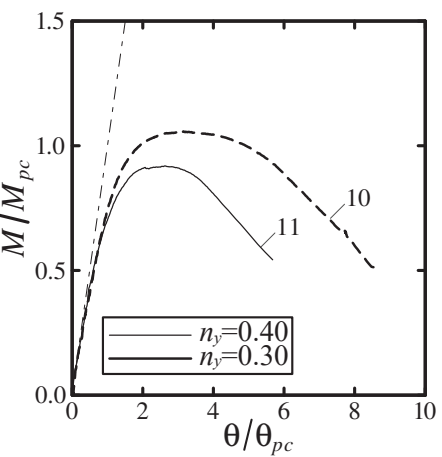

(d) L4200 series
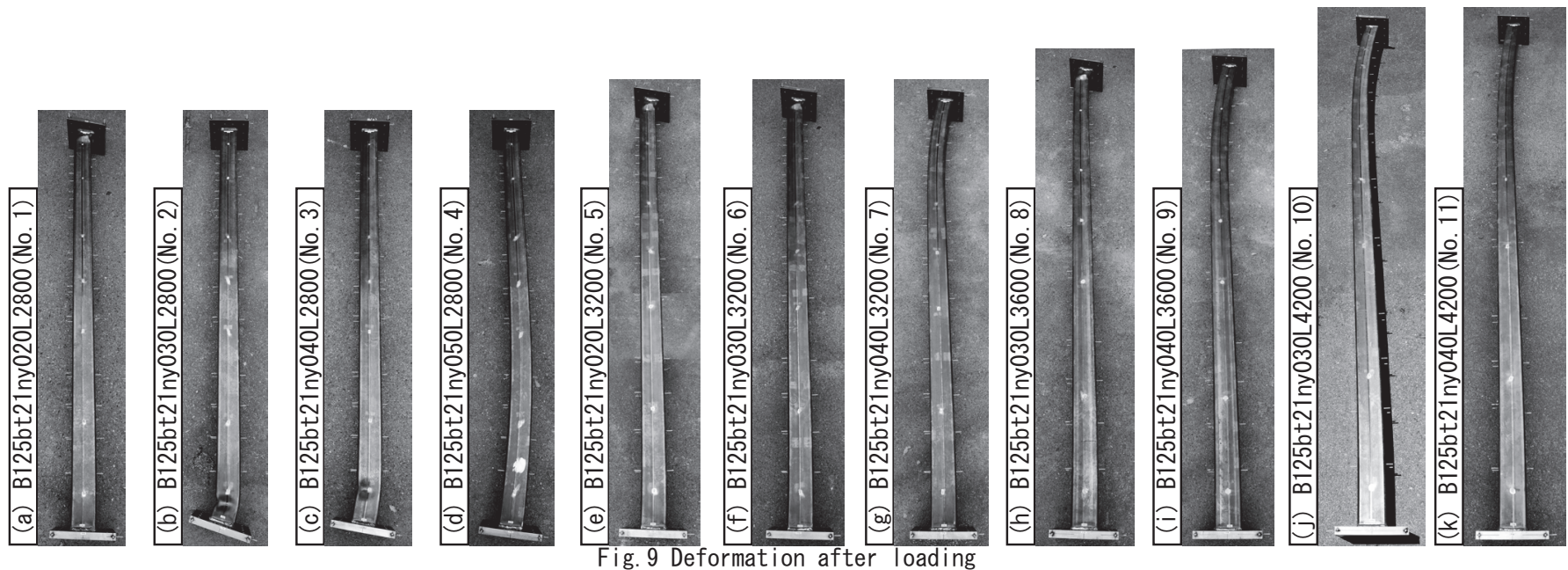

述べる $P \delta$ モーメントについての考察に基づいて行つた．Fig. 8 に示す $\nabla$ 印は局部座屈の発生が確認された時を示している．なお，局部座 屈は目視により判定した. Table 6 に示す $\theta_{\mathrm{u}}$ は載荷点の曲げモーメン トが最大曲げモーメント $M_{\text {max }}$ に至り, 変形を伴い耐力劣化をはじめ, (8) 式に到達した時の材端回転角であり, この時の曲げモーメントを 変形能力評価時曲げモーメント $M_{u}$ とする。

$$
M_{u}=\max \left(0.90 M_{\max }, M_{p c}\right)
$$

C.M.:L となる試験体は最大曲げモーメント到達と同時に，East 側 または West 側の曲げモーメント載荷点付近の圧縮側フランジ面に局 部座屈が生じた。Fig.10(a) に載荷終了時の局部座屈変形性状の様子 を示す，局部座屈が生じた側の曲げモーメント - 回転角関係において は，最大曲げモーメント後，材端回転角の増進に伴い耐力が急激に低 下した。その後の載荷により, 柱端部付近の局部座屈が進展し, 耐力
Table 6 Test results

\begin{tabular}{c|c|c|c|c|c|c|c}
\hline Name & $N_{0}$ & $\mathrm{M}_{\max }$ & $\mathrm{M}_{\max } / \mathrm{M}_{\mathrm{pc}}$ & $\theta_{\max }$ & $\theta_{\mathrm{u}}$ & $\theta_{\mathrm{u}} / \theta_{\mathrm{pc}}$ & $\mathrm{C} . \mathrm{M}$. \\
\hline B125bt21ny020L2800 & 1 & 54.15 & 1.176 & 0.0583 & 0.0769 & 4.63 & $\mathrm{~L}$ \\
\hline B125bt21ny030L2800 & 2 & 49.59 & 1.161 & 0.0652 & 0.0813 & 5.22 & $\mathrm{~L}$ \\
\hline B125bt21ny040L2800 & 3 & 42.50 & 1.119 & 0.0738 & 0.0965 & 6.88 & $P \delta+\mathrm{L}$ \\
\hline B125bt21ny050L2800 & 4 & 34.65 & 1.084 & 0.0536 & 0.0830 & 6.95 & $P \delta$ \\
\hline B125bt21ny020L3200 & 5 & 53.54 & 1.162 & 0.0669 & 0.0865 & 4.52 & $\mathrm{~L}$ \\
\hline B125bt21ny030L3200 & 6 & 47.71 & 1.117 & 0.0707 & 0.0847 & 4.71 & $\mathrm{~L}$ \\
\hline B125bt21ny040L3200 & 7 & 41.08 & 1.081 & 0.0651 & 0.1126 & 6.93 & $P \delta$ \\
\hline B125bt21ny030L3600 & 8 & 52.60 & 1.232 & 0.1013 & 0.0123 & 6.02 & $P \delta+\mathrm{L}$ \\
\hline B125bt21ny040L3600 & 9 & 42.58 & 1.121 & 0.0683 & 0.0116 & 6.21 & $P \delta$ \\
\hline B125bt21ny030L4200 & 10 & 45.17 & 1.058 & 0.0750 & 0.0120 & 4.92 & $P \delta$ \\
\hline B125bt21ny040L4200 & 11 & 34.92 & 0.9191 & 0.0586 & 0.0588 & 2.26 & $P \delta$ \\
\hline$M^{2}$ Maxing
\end{tabular}

$\mathrm{M}_{\max }$ : Maximum bending moment $[\mathrm{kN} \cdot \mathrm{m}], \theta_{\max }:$ Rotation at the maximum bending moment [rad], $\theta_{u}$ : Ultimate rotation [rad], C.M.: Collapse mode 


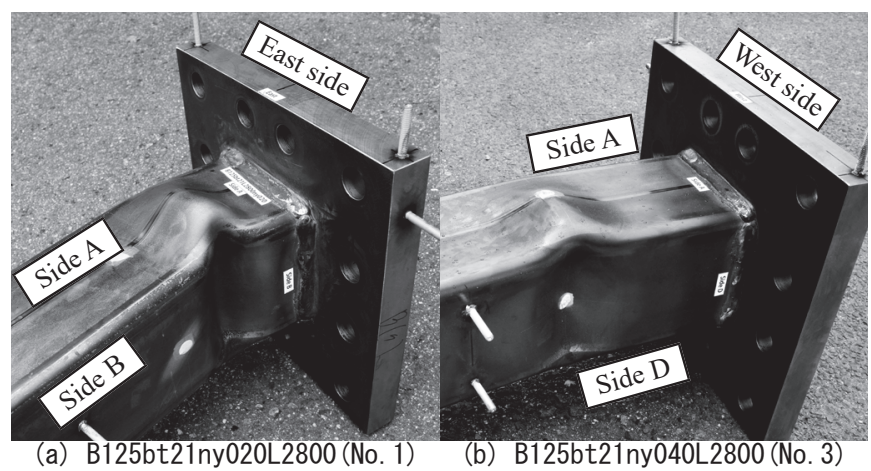

Fig. 10 Local buckling deformation around the loading point

劣化勾配はゆるやかな曲線となった。一方で，局部座屈が生じない側 の曲げモーメント - 回転角関係においては，耐力の低下に伴い回転角 が減退した。耐力低下時の曲線の勾配は初期剛性と同程度であった。 C.M.:P $P+\mathrm{L}$ となる試験体では載荷点での曲げモーメントが最大曲げ モーメント付近に達すると, 片側の材端回転角のみが増進し, もう一 方の載荷点では材端回転角が停滞した。載荷点での曲げモーメントが 最大に至り耐力が低下し始めると, 曲げ面内の最大変位位置の圧縮 側フランジ面に局部座屈が生じた。 Fig.10(b) に載荷終了時の局部座 屈変形性状の様子を示す。回転角が進行し局部座屈が生じた側の曲げ モーメント - 回転角関係においては，耐力の急激な低下に伴い局部座 屈が進展し, 材端回転角が増進した。一方で, 局部座屈が生じない側 の曲げモーメント - 回転角関係においては, 耐力の低下に伴い材端回 転角が減退した。耐力低下時の曲線の勾配は初期剛性と同程度であっ た. C.M.:P となる試験体では, 載荷点での曲げモーメントが最大曲 げモーメント付近に達すると, 片側の材端回転角のみが増進し, もう 一方の載荷点では回転角が停滞した。載荷点での曲げモーメントが最 大に至り耐力が低下し始めると, 材端回転角が増進した側の曲げモー メント - 回転角関係においては, 載荷点から $0.3 \mathrm{~L}$ 程度離机た位置で の曲げ面内変位が最大となる変形を伴い, 耐力低下勾配が連続的に低 下し, 局部座屈が発生することなく耐力を完全に喪失した。一方で, 他方の曲げモーメント - 回転角関係においては, 耐力の低下に伴い回 転角が減退した。耐力減退時の曲線の勾配は初期剛性の $60 \%$ 程度の 緩やかな勾配であった。

Table 6, Fig.7 および Fig.8 に示すように，同一材長の試験体にお いて，軸力比（軸方向圧縮力）が増大すると $P \delta$ モーメントの影響が 大きくなるため, 崩壊形式は局部座屈による崩壊形式から $P \delta$ モーメ ントによる崩壊形式へと変化する。 また, 軸力比の増大に伴い最大 曲げモーメント $M_{\text {max }}$ は低下する。同一軸力比の試験体において, 材 長が長くなると構面内の曲げ面内の変位量も増大するため, $P \delta$ モー メントによる曲げ面内の変形が卓越し, 崩壊形式を決定する変形性 状が局部座屈から $P \delta$ モーメントによる曲げ面内の変形へと変化する.

3. 2. 実験結果と LSD 指針の耐力式・軸力比と細長比による制限との対応 本節では実験により得られた載荷点での最大曲げモーメント $M_{\text {max }}$ と LSD 指針に示された耐力式との対応を確認する。また，実験によ り得られた塑性変形能力・変形性状についての考察を行う。

LSD 指針において, 終局限界状態設計での角形鋼管柱の設計耐力 は, 全塑性限界状態, 曲げ圧縮限界状態, 曲げ引張限界状態および 局部座屈限界状態のうち最も小さい值としている ${ }^{1)}$. ただし，C-1 区 分に属する角形鋼管柱の設計耐力は全塑性限界耐力により決定する
としている ${ }^{1)}$. 本研究で使用した No.1,No.2 および No.5 の試験体は C-1 区分に属することから（2.1 節参照），次の全塑性限界耐力式が適 用される。

$$
\begin{array}{rlrl}
\frac{N}{\phi_{p} N_{y}} & \leq 0.15 \text { のとき } & & \frac{M}{\phi_{p} M_{p}} \leq 1.0 \\
\frac{N}{\phi_{p} N_{y}}>0.15 \text { のとき } & \frac{N}{\phi_{p} N_{y}}+0.85 \frac{M}{\phi_{p} M_{p}} \leq 1.0
\end{array}
$$

本論文では全塑性耐力に関わる耐力係数 $\phi_{p}$ を 1.0 として, 実験よ り得られた載荷点での最大曲げモーメントとの比較を行う。Fig.11(a) に軸方向力を考慮した全塑性モーメント $M_{p c}\left((7)\right.$ 式） ${ }^{21)}$ と実験で得 られた最大曲げモーメント $M_{\text {max }}$ の対応を, Fig.11(b) に全塑性限界 耐力式 ((9) 式) と実験で得られた最大曲げモーメント $M_{\text {max }}$ の対応 を示す. Fig.11 中の番号は試験体番号である. Fig.11(a)に示すよう に, No.11 の試験体を除く, 柱材端に初期降伏が生じる条件式 (5) の 領域内に存在する試験体は，全塑性モーメント $M_{\mathrm{pc}}$ を上回ることが 確認された。柱材端に初期降伏が生じる条件式 (5) の領域外に存在す るNo.11の試験体は, 全塑性モーメント $M_{p c}$ に到達しない. 一方で, Fig.11(b) に示すように, 本論文で扱った試験体の最大曲げモーメン トは LSD 指針の全塑性限界耐力式を上回る結果であった.

縦軸を塑性変形能力 $\mathrm{R}$ とし, 横軸に軸力比 $\mathrm{n}_{\mathrm{y}}$ に曲げ面内細長比 $\lambda_{\mathrm{c} 0}$ の平方を乗じた值 $\left(\mathrm{n}_{\mathrm{y}} \cdot \lambda_{\mathrm{c} 0}{ }^{2}\right)$ とした結果を Fig.12 に示す。 Fig.12 中の番 号は試験体番号である。塑性変形能力 $\mathrm{R}$ の算定式を以下に示す.

$$
R=\theta_{u} / \theta_{p c}-1
$$

Fig.12より，制限式 (2) を満足する試験体（No.1，No.2，No.5）は 局部座屈により塑性変形能力 $\mathrm{R}$ が決定された。本実験で使用した幅厚 比 $\mathrm{B} / \mathrm{t}=21.7$ の試験体では，局部座屈により決定される塑性変形能力 $\mathrm{R}$ は $\mathrm{R}=3.5$ 程度となった。前述したように，LSD 指針では一端曲げ を受ける柱に対して, 制限式 (2) を満たすことで柱材端に塑性ヒンジ を形成し, 塑性変形能力 $R=3 \sim 5$ 以上が確保できるとしているが,

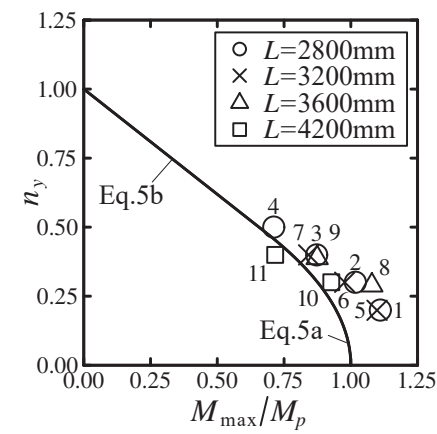

(a) Comparison with Eq. 5

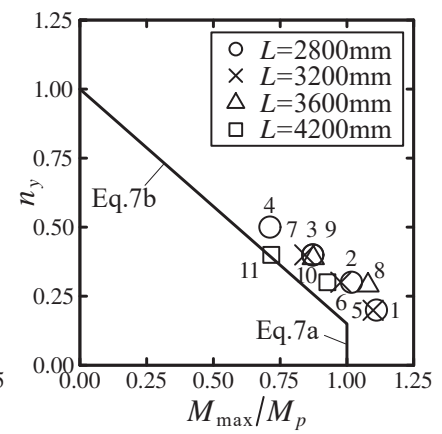

(b) Comparison with Eq. 7
Fig. 11 Comparison between test results and Eq. 5 or Eq. 7

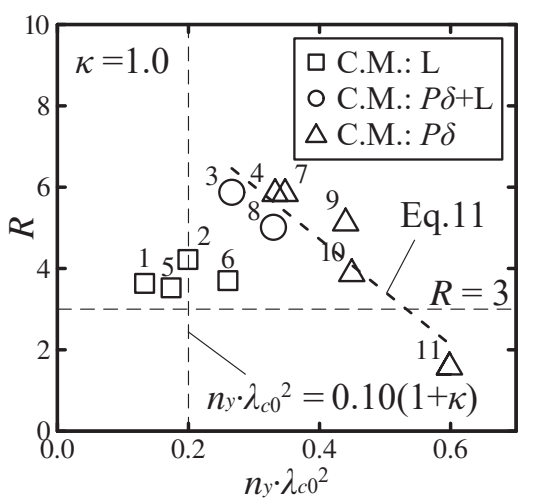

Fig. 12 Plastic deformation capacity $\boldsymbol{R}(\boldsymbol{\kappa}=1.0)$ 
逆対称曲げを受ける柱に対しては，制限式 (2) を満たすことで担保で きる塑性変形能力の具体的な数值を示していない. Fig.12に示すよう に, $n_{y} \cdot \lambda_{c 0}{ }^{2}$ の值が 0.25 より大きい範囲では $P \delta$ モーメントによる影響 で塑性変形能力が決定されることが確認でき, $n_{\mathrm{y}} \cdot \lambda_{\mathrm{c}}{ }^{2}$ の值が 0.45 以下 であ机ば $R=3$ 以上を確保することができた。筆者らは文献 19)にお いて，軸方向圧縮力と一端単調曲げモーメントを受ける角形鋼管柱 で $P \delta$ モーメントによる影響で塑性変形能力が決定される場合は, 塑 性変形能力 $\mathrm{R}$ と $\mathrm{n}_{\mathrm{y}} \cdot \lambda_{c 0}{ }^{2}$ には線形の関係があると報告している。そこで, 本研究で実施した軸方向圧縮力と単調逆対称曲げモーメントを受ける 角形鋼管柱において, P 8 モーメントによる影響で塑性変形能力が決 定される場合（凡例： $\bigcirc, \triangle)$ について, 塑性変形能力と $n_{\mathrm{y}} \cdot \lambda_{\mathrm{c} 0}{ }^{2}$ の関 係を線形関数を用いて回帰分析した。その結果を Fig.12 に示す。図中 の破線で示した回帰式を以下に示す。

$$
R=-13 n_{y} \lambda_{c 0}^{2}+9.92
$$

回帰分析の結果, 相関係数は -0.6071 となり, 負の相関が認められた. 軸方向圧縮力と曲げモーメントを受ける角形鋼管柱の塑性変形能 力は $P \delta$ モーメントにより決定される塑性変形能力と局部座屈により 決定される塑性変形能力の小さい方で決まるといえ, 局部座屈で決 定される塑性変形能力の定量的な評価も重要と言える。したがって,

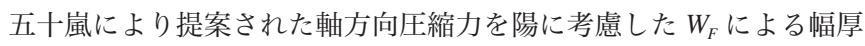
比区分 ${ }^{25)}$ のような, 局部座屈により塑性変形応力が決定される場合 の評価方法が角形鋼管においても必要であると考える.

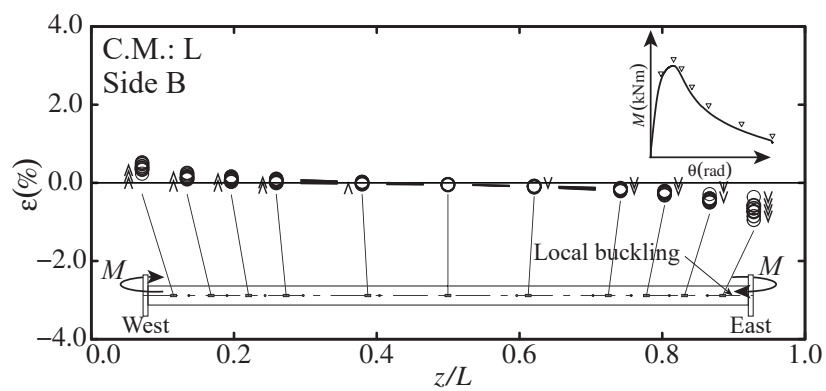

(a) B125bt21ny020L2800

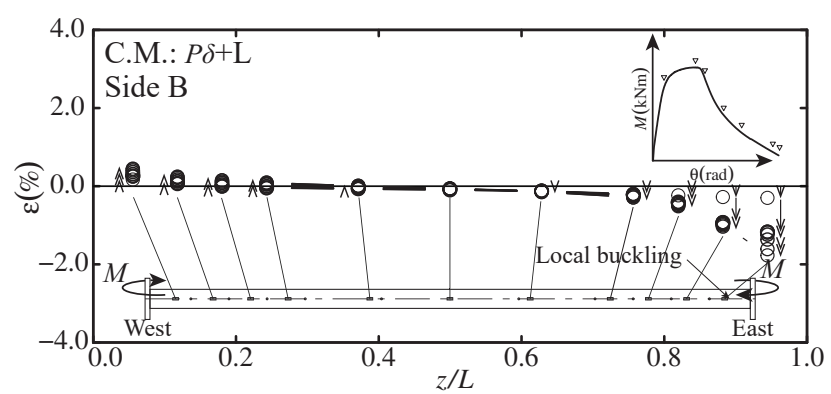

(b) B125bt21ny030L3600

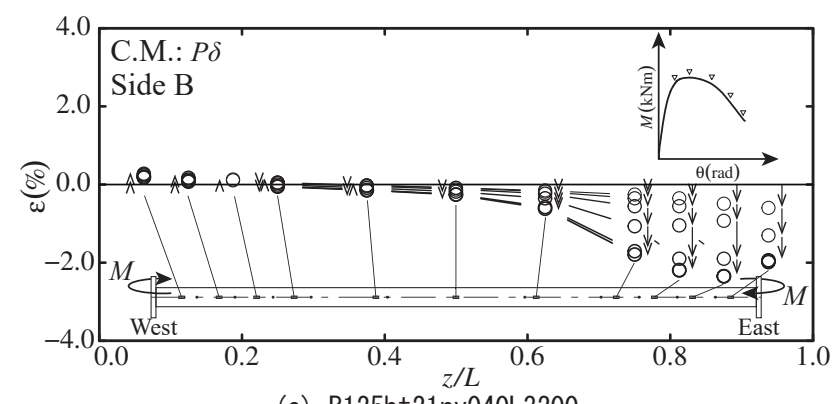

(c) B125bt21ny040L3200

Fig. 13 Strain distribution in the longitudal direction

\section{3. 軸力比と細長比の組合せが部材の歪分布に与える影響}

Fig.13 に崩壊形式毎の歪分布の特徵の差が最も大きく表れた材長方 向歪分布の変化履歴を示す。ここでは材端回転角が進行した側の圧 縮フランジ面の歪を示し，歪を計測した時の曲げモーメント - 回転角

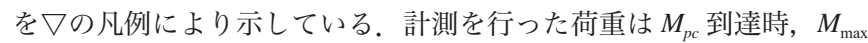
到達時, $\mathrm{M}_{\mathrm{u}}$ 到達時, $0.80 \mathrm{M}_{\text {max }}$ 到達時, $0.60 \mathrm{M}_{\text {max }}$ 到達時, ・ ・吕る. Fig.13(a) は C.M.:L となる試験体を, Fig.13(b) は C.M.:P $P+\mathrm{L}$ となる試 験体を，Fig.13(c) は C.M.:P となる試験体を示している.

Fig.13(a) に示す C.M.:L となる試験体では， $M_{p c}$ 到達時から $M_{\text {max }}$ 到 達時まで中央部の歪は小さく, 両載荷点に近づくほど歪は進行する. 曲げモーメント載荷点付近の圧縮側フランジ面に局部座屈が生じる と, 局部座屈が生じた側の回転角のみが増進するため, 局部座屈が 生じた側の歪が局所的に進行する. Fig.13(b) に示す C.M.:P $P+\mathrm{L}$ とな る試験体では, $M_{p c}$ 到達時まで中央部の歪は小さく, 両載荷点に近づ くほど歪は進行する。 $M_{\text {max }}$ 到達以降は片側の圧縮側フランジ面に局 部座屈が生じるため, 局部座屈が生じた側の回転角のみが増進し, 局 部座屈が生じた側の載荷点から $0.2 \mathrm{~L}$ 程度離れた領域の歪が進行する. Fig.13(c) に示す C.M.:PS となる試験体では，曲げモーメント載荷開始 から試験体が軸方向圧縮力を保持できなくなるまで，面内の曲げ変 形が進行する側の歪が進行し，歪が進行する領域は面内の曲げ変形 が進行する側の載荷点から $0.3 \mathrm{~L}$ 程度離れた領域である. 歪の大きさ は面内の曲げ変形が進行する側の載荷点付近が大きく，他端に近づ

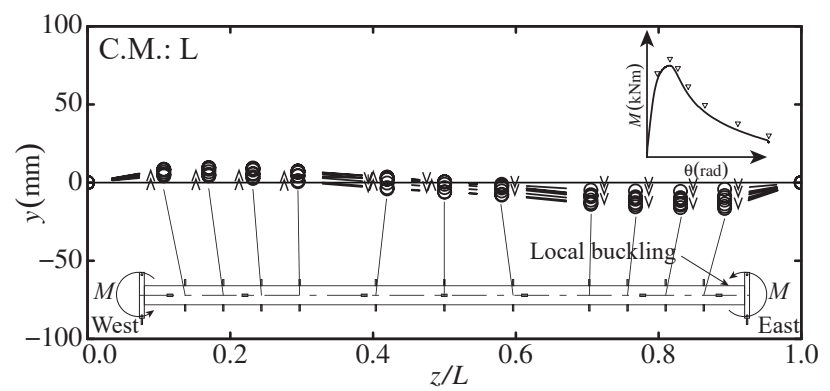

(a) B125bt21ny020L2800

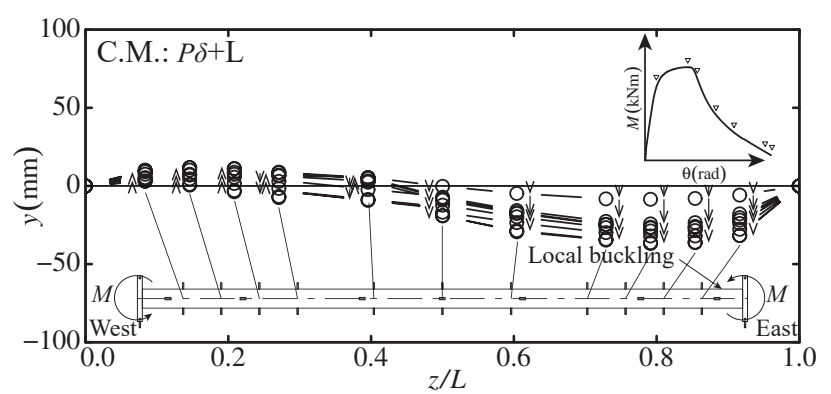

(b) B125bt21ny030L3600

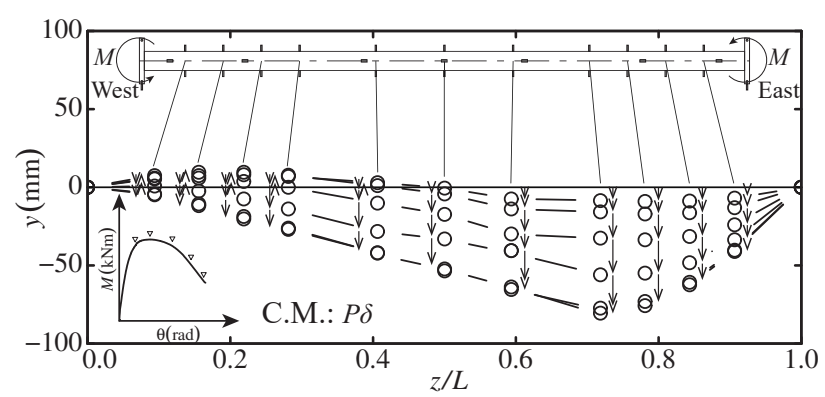

(c) B125bt21ny040L 3200

Fig. 14 In-plane deformation 
くほど小さくなる.

なお，Fig.13に示していない試験体においても，同様の崩壊形式毎 の歪分布の特徵が確認された。

\section{4. 軸力比と細長比の組合せが柱の変形性状に与える影響}

Fig.14 に各水平変位計計測位置での図心の曲げ面内の変位履歴を 示す. 図心の変位履歴を計測した荷重はFig.13 と同様の荷重とした. Fig.14(a) は C.M.:L となる試験体を, Fig.14(b) は C.M.:P $\delta+L$ となる試 験体を, Fig.14(c) は C.M.:P と となる試験体を示している.

Fig.14(a)に示すように C.M.:L となる試験体では，片側の曲げモー メント載荷点付近に局部座屈が発生するため, 材端回転角が進行し ても局部座屈発生領域での変形のみが増大し, 載荷終了時の曲げ面 内の最大変形量は $20 \mathrm{~mm}$ 程度となる。したがって, Fig.9(a),(b),(e),(f) に示す変形性状のように, 試験体は載荷後も局部座屈領域以外はほ とんど曲げ変形が生じない. Fig.14(b) に示す C.M.:P $P+$ L となる試験 体では, $M_{p c}$ 到達後, 曲げ面内の変形が一方向に偏り始める. その後 の載荷において片側の圧縮側フランジ面に局部座屈が生じ，曲げ面 内の変形が一方向に進行した．Fig.14(c) に示す C.M.:P と とる試験体 では, $M_{p c}$ 到達後から試験体が軸方向圧縮力を保持できなくなるまで, 曲げ面内の変形が一方向に偏り, 載荷点の回転角が増進した側での 曲げ面内の変位が進行する. 変形の進行に伴い, $P \delta$ 効果による付加 曲げモーメントが増大し, 耐力低下勾配が連続的に低下したと考元 られる。 なお, $P \delta$ 効果による付加曲げモーメント ( $P \delta$ モーメント) については, 3.5 節において詳しく説明する。 また, いずれの崩壊形 式においても断面のねじれや曲げ面外への変形の進行は確認されな かった。

なお, Fig.14に示していない試験体においても, 同様の崩壊形式毎 の変形性状の特徵が確認された。

\section{5. 軸力比と細長比の組合せが $P \delta$ モーメントに与える影響}

Fig.15 に載荷点での曲げモーメント - 回転角関係と, 水平変位計測 位置における $P \delta$ モーメント - 載荷点での回転角関係との比較を示す. $P \delta$ モーメントは水平変位計位置に打いて計測された水平変位の值に 導入軸方向圧縮力 $\mathrm{N}_{\mathrm{t}}$ を乗じて求めた值である. 以下に, $P \delta$ モーメン トの算定式を示す。

$$
M=N_{t} \cdot \delta_{i}
$$

(12) 式中の下付き文字i は変位計計測位置を意味し, Fig.15 中の 英字は, Fig.1 に示す変位計計測位置を意味する（i = S-B 断面, S-D 断面, , . S S-J 断面)。Fig.15(a) は C.M.:L となる試験体を, Fig.15(b) は C.M.:P $P+\mathrm{L}$ となる試験体を, Fig.15(c) は C.M.:P となる試験体を示し ている.

Fig.15(a) に示す C.M.:L となる試験体では, 最大曲げモーメントに 至るまで $P \delta$ モーメントの絶対值が上昇する. 最大曲げモーメント後

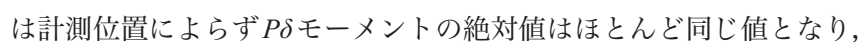
材端回転角が進行しても $P \delta$ モーメントはほとんど増大しないことが 確認できる.これは, 片側の材端に局部座屈が発生し, 局部座屈発 生領域以外での曲げ面内の変形が進行せず, その絶対量も小さかっ たことが要因である (Fig.14(a) 参照). Fig.15(b)に示す C.M.:P $P+\mathrm{L}$ と なる試験体では材端回転角の増大に伴い $P \delta$ モーメントの絶対值が増 大し，その上昇率も C.M.:L となる試験体より大きい. 片側の圧縮側 フランジ面に局部座屈が発生した後は, 曲げ面内の変形が一方向に 進行したため, $P \delta$ モーメントも一方向に集中した. Fig.15(c) に示す

C.M.:PS となる試験体では回転角の進行に伴い, 回転角が増進した載 荷点から $0.3 \mathrm{~L}$ 程度離れた位置での曲げ面内の変位が進行するため, この最大変形位置近傍で $P \delta$ モーメントが大きく増大する.この $P \delta$ 効果により, 最大曲げモーメント後の曲げ面内の変位が大きく進行 し，急激な耐力低下を引き起こしたと考えられる。

Fig.16に柱の図心軸に生じる材長方向の曲げモーメント分布を示 す. Fig.16に示す曲げモーメント分布は，載荷点で作用させた逆対称

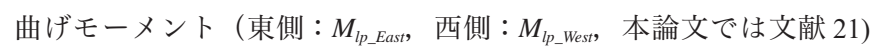
に倣い一次モーメントと呼ぶ）と $P \delta$ 効果による付加曲げモーメント を足し合わせることで算出した（以後, 足し合わせた曲げモーメン トを合算曲げモーメントと称す)。一次モーメントは East 側の載荷点 で計測された曲げモーメント $M_{\text {Ip_East }}$ と West 側の載荷点で計測された 曲げモーメント $M_{\text {Ip_West }}$ を逆対称曲げに直線分布させた。太実線は最 大曲げモーメント到達時の一次モーメントと合算曲げモーメントで あり, 細破線は変形能力評価時の一次モーメントと合算曲げモーメ ントである. (13) 式に合算曲げモーメントの算定式を示す.

$$
M=\left(\left|M_{l p \text { East }}\right|+\left|M_{l p \_ \text {West }}\right|\right) \frac{z}{L}-\left|M_{l p \_ \text {West }}\right|+N_{t} \cdot \delta_{i}
$$

(13)式中の下付き文字i は, Fig.1 に示す変位計計測位置を意味する (i

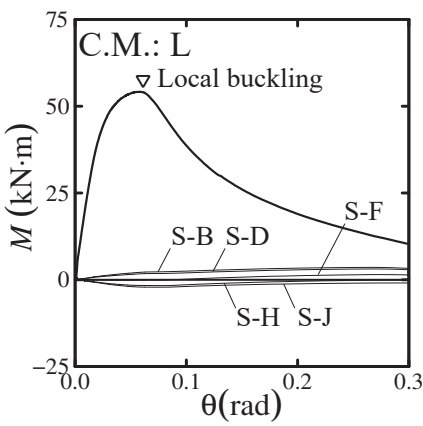

(a) B125bt21ny020L2800

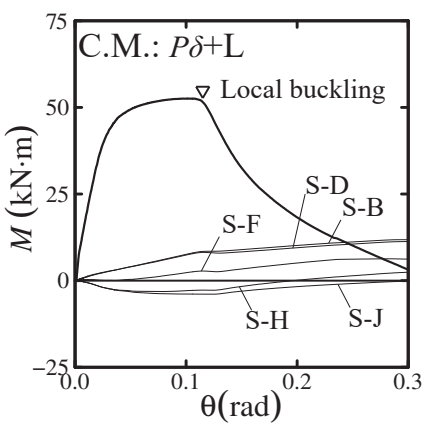

(b) B125bt21ny030L3600

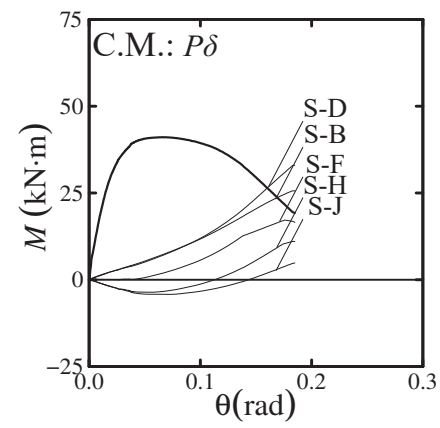

(c) B125bt21ny040L3200

Fig. 15 Comparison between end bending moment and $\boldsymbol{P} \boldsymbol{\delta}$ moment

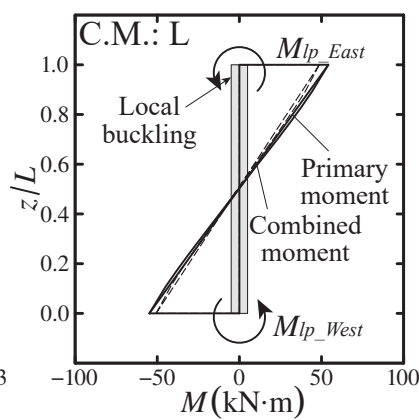

(a) B125bt21ny020L2800

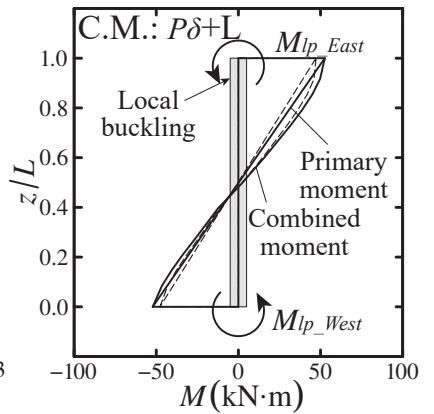

(b) B125bt21ny030L 3600

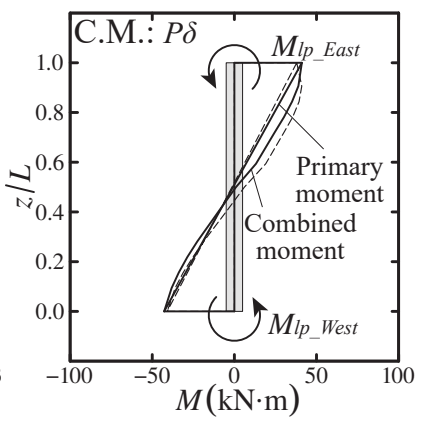

(c) B125bt21ny040L3200

ig. 16 Bending moment distribution in the longitudal direction 
Table 7 Comparison between combined moment and $\boldsymbol{M}_{\max }$ or $\boldsymbol{M}_{\boldsymbol{u}}$

\begin{tabular}{|c|c|c|c|c|c|c|c|c|}
\hline Name & No & C.M. & $M_{\text {max }}$ & S-i & $\mathrm{M}_{\mathrm{i}} / \mathrm{M}_{\max }$ & $\overline{M_{u}}$ & S-i & $\mathrm{M}_{\mathrm{i}} / \mathrm{M}_{\mathrm{u}}$ \\
\hline $25 \mathrm{bt} 21 \mathrm{n}$ & 1 & L & \begin{tabular}{|l|l|}
54.15 \\
\end{tabular} & S-K & 0.831 & 48.73 & S-K & 0.860 \\
\hline & 2 & $\mathrm{~L}$ & 49.59 & S-K & 0.860 & 44.63 & S-K & 0.874 \\
\hline & 3 & $\delta+\mathrm{L}$ & 42.50 & S-K & 931 & 38.2 & S-K & 0.98 \\
\hline & 4 & $P \delta$ & 34.65 & S-K & 0.958 & 31.98 & S-K & 1.10 \\
\hline & 5 & $\mathrm{~L}$ & 53.54 & S-K & 0.872 & 48.19 & S-K & 0.906 \\
\hline 125 & 6 & $\mathrm{~L}$ & 47.71 & S-K & 0.904 & 42.94 & S-K & 0.932 \\
\hline & 7 & $P \delta$ & 41.08 & S-A & 0.948 & 37.99 & S-A & 1.080 \\
\hline & 8 & $P \delta+\mathrm{L}$ & 52.60 & S-A & 0.946 & 47.34 & S-A & 0.973 \\
\hline & 9 & $P \delta$ & 42.58 & S-A & 0.975 & 38.32 & S-B & 1.140 \\
\hline $125 \mathrm{bt} 21 \mathrm{ny}$ & 10 & $P \delta$ & 45.17 & S-K & 0.988 & 42.70 & S-K & 1.094 \\
\hline 200 & 11 & $P \delta$ & 34.92 & S-A & 1.034 & 37.9 & S-C & 0 \\
\hline
\end{tabular}

= S-A 断面, S-B 断面, , ․, S-K 断面)。Table 7 に載荷点で計測された最 大曲げモーメント $M_{\text {max }}$ に対する合算曲げモーメントの最大值の比率 $M_{i} / M_{\text {max }}$, 変形能力評価時曲げモーメント $M_{u}$ に対する変形能力時の合 算曲げモーメントの最大值の比率 $M_{i} / M_{4}$ を示す。また，その計測位 置を Table 7 に示している. 載荷点で計測された最大曲げモーメント $M_{\text {max }}$ に対する合算曲げモーメントの最大值の比率 $M_{\mathrm{i}} / M_{\text {max }}$ は既往の 研究で示されるモーメント拡大係数 ${ }^{14), 25)}$ に相当し, 各指針の軸方向 力と曲げモーメントの耐力相関式に組み込まれている ${ }^{1)}$ ）． Fig.16(a) は C.M.:L となる試験体を, Fig.16(b) は C.M.:P $P+\mathrm{L}$ となる試験体を, Fig.16(c) は C.M.:P となる試験体を示している.

Fig.16(a)に示す C.M.:L となる試験体では材端付近に局部座屈が 生じ, 曲げ面内の変形がほとんど進行しないため, $P \delta$ 効果による 付加曲げモーメントの割合は小さく, 柱材端の最大曲げモーメント に対する合算曲げモーメントの最大值の比率 $M_{i} / M_{\text {max }}$ は 0.85 程度に 留まる. 変形能力評価時に生じる合算曲げモーメントにおいてもそ の比率は 0.90 程度に留まり, 材端の曲げモーメントが最大となる. Fig.16(b) に示す C.M.: $P \delta+\mathrm{L}$ となる試験体では $P \delta$ 効果による付加曲げ モーメントの影響が大きくなり, 柱材端の最大曲げモーメントに対 する合算曲げモーメントの最大值の比率 $M_{i} / M_{\text {max }}$ は 0.95 程度になる. 変形能力評価時には $P \delta$ モーメントの影響が大きくなるため, 合算曲 げモーメントの比率は 1.0 に近くなる. Fig.16(c) に示す C.M.:P $P \delta$ な る試験体では最大曲げモーメント時において, P 8 効果による付加曲 げモーメントの割合が 1.0 程度と高い值となり, 柱部材内の曲げモー メントが大きく, 最大曲げモーメント到達直後に急激な耐力低下が 生じる. 変形能力評価時においては, 最大曲げモーメント時と比較し, 柱部材内の合算曲げモーメントはさらに増大するため, 軸方向圧縮 力を保持できなくなる.

なお，Fig.15および Fig.16に示していない試験体においても，同 様の崩壊形式毎の材長方向の曲げモーメント分布の特徵および曲げ モーメント拡大係数 $M_{\mathrm{i}} / M_{\text {max }}$ の特徵が確認された.

LSD 指針では, $P \delta$ モーメントの影響により最大曲げモーメントが 材端に生じない場合について, 材端曲げモーメントに $P \delta$ モーメント を考慮する係数（モーメント拡大係数 ${ }^{14), 26)}$ ) を乗じることで柱に生 じる最大曲げモーメントを評価する方法を採用している．P $P \delta$ モーメ ントを考慮するモーメント拡大係数 $\varphi$ は以下の式が適用されている. $n_{y} \cdot \lambda_{c 0}^{2} \leq 0.25(1+\kappa)$ のとき $\varphi=1.0$

$n_{y} \cdot \lambda_{c 0}^{2}>0.25(1+\kappa)$ のとき $\varphi=\frac{1-0.5(1+\kappa) \cdot \sqrt{N / N_{0}}}{1-N / N_{0}}$

ここで, $N_{0}$ は材長 $L$ を座屈長さとする柱のオイラー座屈耐力であ
る $\left(=\pi^{2} E I / L^{2}\right)$. 材端に初期降伏が生じる条件式 (2) を満たす柱は (14.a) 式が適用され，それ以外の柱は (14.b) 式より求まる 1.0 以上 ${ }^{14)}$ の值 を乗じることになる. No.11 を除く試験体は柱材端に初期降伏が生じ る領域内に存在することから，モーメント拡大係数 $\varphi$ は 1.0 となり部 材の最大曲げモーメント位置が材端となる。すなわち, 柱耐力は材 端曲げモーメントが軸方向圧縮力を考慮した全塑性モーメント $M_{\mathrm{pc}}$ に 達することで決まることになる。このことは, Fig. 10 で示したように, 材端での最大曲げモーメントが (9) 式で示した全塑性限界耐力式 ${ }^{1)}$ 超えた結果と一致する。 また, Fig.16および Table 7 で示したように, 載荷点で計測された最大曲げモーメント $M_{\text {max }}$ に対する合算曲げモー メントの比率 $\mathrm{M}_{\mathrm{i}} / \mathrm{M}_{\max }$ は C.M.:L となる試験体と C.M. $: P \delta+\mathrm{L}$ となる試 験体では 1.0 より小さな值となる。 すなわち, 材端での曲げモーメン トが最大となり，(14) 式と一致する. C.M.:P と とる試験体では, $M_{i}$ $/ \mathrm{M}_{\text {max }}$ の值は最大曲げモーメント時において 1.0 程度の值であり, (14) 式と一致するが, 変形能力評価時には 1.0 を超える值となる.

軸方向圧縮力と逆対称曲げモーメント $(\kappa=1.0)$ を受ける角形鋼 管柱に対し，LSD 指針では制限式 (2) を満足することで担保するこ とができる塑性変形能力の值を示していない. Fig.12で示したよう に, $n_{y} \cdot \lambda_{c 0}{ }^{2}$ の值が 0.45 以下の角形鋼管柱, すなわち, 制限式 (2) が規 定する $n_{y} \cdot \lambda_{c 0}{ }^{2}$ の值で 0.20 以上の角形鋼管柱であっても, 塑性変形能 力 $\mathrm{R}=3$ 以上を確保することが本研究により明らかとなった。 しかし, $n_{\mathrm{y}} \cdot \lambda_{\mathrm{co}}{ }^{2}$ の值が 0.25 以上の角形鋼管柱では崩壊形式が $P \delta$ モーメントで 決定され, 材端での初期降伏後, 曲げ面内の曲げ変形により崩壊形 式が決定されるため, 設計で想定する材端での塑性ヒンジの変形に よる崩壊機構が形成されない結果となった（Fig.9参照）。設計では, 全塑性モーメントに到達した材端部で塑性ヒンジが形成され，塑性 変形が進行することで終局状態に至ることを意図していることから, $P \delta$ モーメントにより柱材端から離れた位置が最大曲げモーメントと なる崩壊形式は避けるべきと言える。本論文で実施した単調逆対称 曲げ実験の結果の範囲では, $n_{y} \cdot \lambda_{c 0}{ }^{2}$ が 0.25 以下であれば, 曲げ面内の 曲げ変形による崩壊形式は生じず，材端付近に塑性変形が集中する 崩壊形式を確保できており, 変形性状の観点から考察すると, LSD 指針の制限は適当であると言える.

\section{4. まとめ}

本論文では軸方向圧縮力と単調逆対称曲げモーメントを受ける角 形鋼管柱の実験を行い, 軸力比, 細長比が角形鋼管柱の最大曲げモー メント, 塑性変形能力, 変形性状に与える影響を考察した。 以下に 結論をまとめる。

1) 載荷中に観察された試験体の挙動, 試験体に貼付した歪ゲージか ら得た材長方向の歪分布, 曲げ面内の変位履歴, $P \delta$ モーメント についての考察に基づいて分類を行った柱の崩壊形式として, 次 の 3 つの変形性状が確認された.

i) 片側の曲げモーメント載荷点付近に発生した局部座屈により 載荷点の最大曲げモーメントおよび変形能力が決定された崩 壊形式

ii) $P \delta$ モーメントによる変形で載荷点での最大曲げモーメントが 決定され, その後, $P \delta$ モーメントの影響により生じる曲げ面 内の最大変位位置に顕著な局部座屈変形が生じ, 変形能力が 決定された崩壊形式 
iii) $P \delta$ モーメントにより載荷点での最大曲げモーメントおよび変 形能力が決定され, その後, 局部座屈が生じることがなく部 材の曲げ面内の変形が一方向に進行し, 載荷点から $0.3 \mathrm{~L}$ 程度 離れた位置の曲げ面内変位が最大となった崩壊形式

2) $n_{y} \lambda_{c 0}{ }^{2}$ (軸力比 $n_{y}$ と曲げ面内細長比 $\lambda_{c 0}$ の平方の積）の值が 0.25 より大きい範囲では $P \delta$ モーメントによる影響で塑性変形能力が 決定された。塑性変形能力 $\mathrm{R}$ と $n_{\mathrm{y}} \cdot \lambda_{\mathrm{co}}{ }^{2}$ には負の相関があり, 相関 係数は -0.6071 であった。 $\mathrm{n}_{\mathrm{y}} \cdot \lambda_{\mathrm{co}}{ }^{2}$ が 0.25 以下であれば, 柱材端付 近に塑性変形が集中した。本実験で使用した幅厚比 $B / t=21.7$ の 試験体では, 局部座屈により決定される塑性変形能力 $\mathrm{R}$ は $\mathrm{R}=3.5$ 程度を確保することができた。

3) 軸方向圧縮力と曲げモーメントを受ける角形鋼管柱の塑性変形能 力は $P \delta$ モーメントにより決定される塑性変形能力と局部座屈に より決定される塑性変形能力の小さい方で決まるといえ，局部座 屈で決定される塑性変形能力の定量的な評価も重要と言える.

4) 軸力比と細長比の組み合わせによっては, LSD 指針が塑性ヒン ジを形成する柱に対して定める制限の領域外に存在する柱であっ ても, 塑性変形能力 $\mathrm{R}=3$ 程度を確保することができる。しかし, 崩壊形式が $P \delta$ モーメントで決定される柱は, 曲げ面内の曲げ変 形によって崩壊が決定されるため, 設計で柱に想定する崩壊形式 とは異なることが確認された。柱材端付近に塑性変形が集中する 崩壊形式を確保するためには，本実験の範囲では LSD 指針の制 限が適当と言える.

\section{謝辞}

本研究の一部は科学研究費補助金・基盤研究 (C)（課題番号 15K06291，代表研究者：佐藤篤司）を受けて行ったものであります. 付して感謝の意を表します。

\section{参考文献}

1) 日本建築学会 : 鋼構造限界状態設計指針 - 同解説，2010.2

2) 日本建築学会 : 鋼構造塑性設計指針, 2010.2

3) 日本建築学会 : 鋼構造座屈設計指針, 2009.11

4) 日本建築学会 : 鋼構造設計規準 - 許容応力度設計法 -, 2005.9

5) 岡信行, 中島正愛, 辻文三 : サイドスウエイをともなう鉄骨柱材における P $\Delta$ 効果の評価, 日本建築学会大会学術講演梗概集， C, 構造 II, pp.13451346, 1993.9

6) 津田惠吾 : 節点移動のある均等な骨組の柱材の実用座屈長さ評価式, 日本 建築学会構造系論文集，第 545 号，pp.151-155，2001.7

7) 井上一郎, 吹田啓一郎：P $\Delta$ 効果による柱の付加曲げモーメント, 日本建 築学会大会学術講演梗概集, C-1, 構造III, pp.759-760, 2008.9

8) 蘇鐘, 佐藤篤司, 吹田啓一郎：地震時に鋼柱に作用する P $\Delta$ モーメントの 簡易予想, 日本建築学会大会学術講演梗概集, C-1, 構造 - III, pp.683-684, 2009.7

9) 山崎真司 : 複曲率曲げを受ける鋼柱の塑性変形能力, 日本建築学会大会学 術講演梗概集, C-1, 構造 - III, pp. 833-834, 2004.7

10) 山田稔, 辻文三, 徳田京誠 : 複曲率曲げを受ける角形鋼管柱の弾塑性変形 挙動および崩壊性状に関する研究 $\mathrm{I}$ 一方向載荷 $\mathrm{N}=1 / 3 \mathrm{~N}_{\mathrm{y}}$, 日本建築学会大 会学術講演梗概集，構造系，pp. 1923-1924， 1982.8

11) 津田惠吾, 松井千秋：一定軸力下で水平力を受ける角形鋼管柱の耐力, 日 本建築学会構造系論文集，第 512 号，pp.149-156，1998.10

12) 三谷勲, 松井千秋, 津田惠吾 : 角形鋼管柱の塑性変形能力評価式, 日本建 築学会大会学術講演梗概集, 構造系, pp.1299-1300, 1984.9
13) 早坂昌彦, 中野達也, 増田浩志 : 軸力と曲げを受ける角形鋼管柱の力学 性能に関する研究, 日本建築学会大会学術講演梗概集, C-1, 構造III, pp.647-648, 2007.8

14) 津田惠吾, 城戸將江 : 完全弾塑性型の応力 - ひずみ関係よりなる角形鋼管 柱の終局耐力評価について，日本建築学会構造系論文集，第 80 巻，第 718 号, pp.1981-1990, 2015.12

15) 佐藤篤司 : 圧縮軸力と強軸まわりに曲げモーメントを受ける $\mathrm{H}$ 形鋼断面柱 の曲げ面内挙動, 日本建築学会研究報告九州支部, 1. 構造系 (55), pp.361$364,2016.3$

16) 鈴木敏郎, 小野徹郎，加藤征宏 : 圧縮と曲げを受ける柱の変形能力に関す る実験，日本建築学会大会学術講演梗概集，構造系，pp.1009-1010，1976.8

17) 鈴木敏郎, 小野徹郎 : 圧縮と曲げを受ける鉄骨 $\mathrm{H}$ 形断面柱の塑性変形能 力に関する研究その 1 , 日本建築学会論文報告集，第 292 号，pp.23-29, 1980.6

18) 石田交広, 小野徹郎, 野元覚 : 実験デー夕に基づく鉄骨曲げ柱の設計規範 に関する一考察，日本建築学会大会学術講演梗概集，C，構造 II，pp.12871288, 1989.10

19) 山田風人, 三井和也, 佐藤篤司 : 圧縮軸力と曲げモーメントを受ける角形 鋼管柱に関する研究，その 1: 一端単調曲げ実験，その 2: 実験結果の考察， 日本建築学会大会学術講演梗概集，C-1，構造 - III，pp.1011-1014， 2016.8

20) 樋口満, 金子洋文, 原田宏一, 森田耕次: ノンダイヤフラム形式のコンクリー 卜充填円形鋼管柱・柱フランジ接合部の局部引張耐力に関する研究 - その 1- 降伏線理論による接合部局部耐力評価, 日本建築学会構造系論文集, 第 536 号, pp.177-184, 2000.10

21) 井上一朗, 吹田啓一郎 : 建築鋼構造 - その理論と設計 -, 鹿島出版, 2010.2

22) 伊藤綾那，清水信孝，佐藤圭一，河合良道 : 軸力の方向に応じた機械的特 性を考慮した円形鋼管の有限要素解析，鋼構造年次論文報告集，第 23 巻， pp. 446- 451， 2015.11

23) 佐藤公亮, 五十嵐規矩夫 : 初期不整が冷間成形角形鋼管部材の大変形挙動 に与える影響, 構造工学論文集, Vol.60B, pp. 327-334, 2014.3

24) 山田隼地, 佐藤篤司, 小野徹郎 : 軸力と曲げモーメントを受ける鋼柱の座 屈実験装置, 日本建築学会大会学術講演梗概集, C-1, 構造 - III, pp.549$550, \quad 2015.9$

25) 五十嵐規矩夫，長谷川龍太 : 新規幅厚比指標による $\mathrm{H}$ 形断面柱の局部座屈 耐力および塑性変形能力評価その 2 新規幅厚比指標による軸力を考慮し た部材性能評価, 日本建築学会大会学術講演梗概集, 構造 - III, pp.12191220, 2013.8

26) 日本建築学会 : 鋼構造物の座屈に関する諸問題 2013, 2013.6 


\title{
EXPERIMENTAL STUDY ON SQUARE STEEL TUBULAR COLUMNS \\ UNDER COMPRESSIVE AXIAL FORCE WITH MONOTONIC ANTISYMMETRIC BENDING MOMENT
}

\author{
Atsushi SATO* and Kazuya MITSUI** \\ * Assoc. Prof., Graduate School of Engineering, Nagoya Institute of Technology, Dr.Eng. \\ ** Doctoral Student, Dept. of Scientific and Engineering Simulation, Nagoya Institute of Technology
}

In Japan, square steel tubular columns are widely used. When the building is subject to a seismic load, columns will subject axial force with antisymmetric bending moment simultaneously. Therefore, it is important to design the column under these combined loading in the ultimate limit state to guarantee the safety. Recommendation for Limit State Design of Steel Structure (LSD) specifies the requirements for columns to guarantee sufficient strength and ductility. The plastic deformation capacity of the columns that are subjected to compressive axial force with one end monotonic bending moment are ensured more than 3 by LSD. However, specific deformation capacity of the column that are subjected to compressive axial force with monotonic antisymmetric bending moment is not shown. Test results that can confirm the appropriateness of LSD requirements for square steel tubular column are limited. It is necessary to gather more data of maximum strength, deformation capacity, and elasto-plastic behavior of square steel tubular columns by testing. Moreover, column that is subjected to compressive axial force is important to take into account second-order effects.

In this study, testing where axial force with monotonic antisymmetric bending moment are applied to the columns simultaneously are conducted. Maximum bending moment, deformation capacity, and second-order effect that will be caused by $P \delta$ moment were evaluated from the test results. Comparison between LSD requirements and test results were also shown.

From the test results, followings are found.

1) Three types of collapse mechanism are confirmed.

i) Local buckling occurred at one end of the column determined the ultimate state and deformation capacity.

ii) $P \delta$ moment determined the moment capacity at the loading point. After the maximum bending moment, local buckling occured at the maximum deflection point and it determined the ultimate state and deformation capacity.

iii) $P \delta$ moment determined the moment capacity at the loading point; increment of the bending deflection determined the ultimate state. Local buckling was not observed during the testing.

2) When the value of $n_{y} \cdot \lambda_{c 0}{ }^{2}$ is larger than 0.25 , second-order effects determined the plastic deformation capacity. Plastic deformation capacity $R$ of the columns that were determined by $P \delta$ moment had a linear relation between $n_{\mathrm{y}} \cdot \lambda_{c 0}{ }^{2}$. When the value of $n_{\mathrm{y}} \cdot \lambda_{c 0}{ }^{2}$ is smaller than 0.25 , plastic hinge was formed at the end of the column and determined the collapse mechanism. Width-to-Thickness ratio equals to 21.7 that was used in the testing and collapsed by local buckling had a plastic deformation capacity around 3.5.

3) Plastic deformation capacity of the square steel tubular column will be determined by either local buckling or $P \delta$ moment. It was found that deformation capacity of the columns that were determined by $P \delta$ effects have a linear relationship between $\mathrm{n}_{\mathrm{y}} \cdot \lambda_{\mathrm{c} 0}{ }^{2}$; therefore, it is also important to evaluate quantitatively the plastic deformation capacity which is determined by local buckling.

4) Plastic deformation capacity greater than 3 were observed even if the current LSD limitation was not satisfied. However, from the point of view of collapse mechanism, LSD limitation can form a plastic hinge at the end of the column which is expected in design. 